Journal of Internet Cataloging, 2003, Vol. 6, No. 2, p.35-90.

ISSN: 1091-1367

DOI: $10.1300 / \mathrm{J} 141 \mathrm{v} 06 \mathrm{n} 02.06$

http://www.taylorandfrancis.com/

http://www.tandfonline.com/toc/wzic20/current

http://www.informaworld.com/smpp/ftinterface $\sim \mathrm{db}=\mathrm{all} \sim$ content $=\mathrm{a} 909291670 \sim$ fulltext $=713240930$

(C) 2003 The Haworth Press, Inc. All rights reserved.

\title{
Selected Cataloging Tools on the Internet
}

\author{
Magda El-Sherbini
}

\begin{abstract}
This bibliography contains selected cataloging tools on the Internet. It is divided into seven sections as follows: authority management and subject headings tools; cataloging tools by type of materials; dictionaries, encyclopedias, and place names; listservs and workshops; software and vendors; technical service professional organizations; and journals and newsletters. Resources are arranged in alphabetical order under each topic. Selected cataloging tools are annotated. There is some overlap since a given web site can cover many tools.
\end{abstract}

\section{INTRODUCTION}

Selected Cataloging Tools on the Internet refers to a vast collection of cataloging tools used by catalogers to perform their work. Until recently these tools existed only in print. With the advent of the Internet, many of these tools became easily accessible in electronic formats on the Web.

Although these tools do not replace their print counterparts, they offer the convenience of being available at the cataloger's workstation and at their fingertips. They are also more current than some of the print resources and thus help avoid some inconsistencies in applying the rules. Cataloging tools available on the Internet provide a quick service to catalogers. They are reliable and updated frequently.

Today's catalogers are able to apply multitasking and open many sessions on their PCs, enabling them to have free access to the documentation they need as they perform their work. It is common for catalogers to bookmark their favorite sources and tools they use. Such a simple concept led to the creation of this extensive, annotated bibliography.

Selected Cataloging Tools on the Internet is an extensive compilation of web-based resources and it provides catalogers with organized access to commonly used tools on the Internet. Annotations included with each entry provide a quick thumbnail sketch for each site, enabling the cataloger to choose what is needed. Some of the annotations are longer than others and some include quotations from the web site. There is some overlapping since a given website can cover many tools.

This bibliography is divided into the following seven sections:

Authority management and subject headings tools Cataloging tools by type of material: 
Books

Foreign Language Materials

Government Publications

Internet/Electronic Resources

Music

Non-book

Rare Books

Serials

Theses and Dissertations

Dictionaries, encyclopedias, and place names

Listservs and workshops

Software and vendors

Technical service professional organizations

Journals and newsletters

Resources are arranged in alphabetical order under each topic.

\section{AUTHORITY MANAGEMENT AND SUBJECT HEADINGS TOOLS}

This section provides selected links to web sites that include information on authority management and subject headings tools.

655 Form/Genre Headings

http.//www.carl.org/tlc/crs/bib1191.htm

This web site includes links to Field Definition and Scope, Guidelines for Applying Content Designators, Input Conventions (such as punctuation, spacing and sub-fields, and display), Content Designator History, and related MARC fields or documents.

Authority Control: Full Bibliography

http://ublib.buffalo.edu/libraries/units/cts/ac/ac_bib.html

This is a comprehensive bibliography on authority control created by Stacy Person, University at Buffalo Libraries. It is arranged in alphabetical order and by subject.

Authority Control in the 21st Century. Proceedings

http://www.oclc.org/oclc/man/authconf/procmain.htm

Conference papers from a meeting held at OCLC March 31 -April 1, 1996.

Authority Maintenance

http.//www.itcompany.com/inforetriever/cat_auth.htm

This is from the Internet Library for Librarians and it provides links to the following sites: 
Authority Control in the 21st Century: Proceedings

OCLC Authority Control

Data Research Associates.

Library of Congress Authority File

Library Technologies, Inc.

Fact Sheet: Medical Subject Headings (MeSH)

http://www.nlm.nih.gov/pubs/factsheets/me.sh.html

This web site includes the Thesaurus; MeSH Applications; Establishing and Updating $\mathrm{MeSH}$; and MeSH Publications.

The Future Is Now: Reconciling Change and Continuity in Authority Control: Proceedings of the OCLC Symposium, ALA Annual Conference, June 23, 1995

http://www.oclc.org/oclc/man/9391ausy/toc.htm

This is the third symposium of the OCLC series "The Future Is Now." This symposium includes extensive discussion and issues on authority control.

Geographic Names Information System

http://geon.ames. usgs.gov/

http://www-nmd.usgs.gov/www/gnis/

The Geographic Names Information System (GNIS) was developed by the USGS in cooperation with the U.S. Board on Geographic Names (BGN). It is the official U.S. repository of domestic geographic names and contains information about almost 2 million physical and cultural geographic features.

If You Like

http://www.hennepin.lib.mn.us/pub/reader2reader/iyl.html

A handy reference guide to authors and genres.

Library of Congress Authority File

http://authorities.loc.gov/

Searching the Library of Congress Authority File by author, subject, title, call number and other criteria.

Library of Congress Subject Heading (LCSH): Principles of Structure and Policies for Application: Contents http://www.carl.org/tlc/crs/shed0014.htm

http://www.tlcdelivers.com/tlc/crs/shed0014.htm

These sites provide an introduction to LCSH; Principles of Headings Construction; Policies for Assigning Subject Headings and; Reference Source Document-From the 
Cataloger's Reference Shelf (http://www. tlcdelivers.com/tlc/crs/crs0000.htm).

Library of Congress Subject Headings Weekly Lists

http://lcweb.loc.gov/catdir/cpso/wlsabt.html

This is a weekly list of additions and changes to the Library of Congress Classification. This information was formerly made available in a quarterly publication entitled LC Classification: Additions and Changes. That publication ceased with List 284 (OctoberDecember 2001.).

Library Technologies, Inc.

http://www.librarytech.com/ACTOC.HTM

LTI offers name and subject authority control based on the Library of Congress name and subject authority databases. LC authority files include more than 4.9 million name authority and 253,000 subject authority records. These files are supplemented by 1.5 million LTI name and subject authority records for which no LC authority is available.

MARC 21 Format for Authority Data

http://www.tlcdelivers.com/tlc/crs/Auth0001.htm

This site links to the Introduction to the MARC 21 Format for Authority Data, Leader, Directory, Variable Control Fields (00X), Variable Data Fields (0XX-9XX), Appendices, LC Guidelines for Usage, Glossary, and Tag List (001-999). This document is intended for the use of personnel involved in the creation and maintenance of authority records, as well as those involved in the design and maintenance of systems for the communication and processing of MARC 21 records.

NACO Participant's Manual, 2nd ed. Library of Congress, Washington D.C. 1996 http://www.loc.gov/catdir/pcc/naco/npm2ed.pdf

This web site links to the NACO Participant's Manual.

NACO Program for Cooperative Cataloging

http://lcweb.loc.gov/catdir/pcc/naco.html

The name authority program (NACO) component of the PCC. Through this program, participants contribute authority records for names, uniform titles, and series to the national authority file. This web page includes information on how individual institutions may join this program.

OCLC Authority User Guide 
http://www.oclc.org/oclc/man/541laug/toc_nofr.htm

This site provides a link to the OCLC Authorities User Guide. This guide provides information about how to use PRISM Authorities and includes the following sections: an introduction, system access and operation, enter searches, view search result, create, maintain, and edit records, contribute and export records and other information.

Pattern Headings

http://130.15.161.74/techseiy/auth/09Subjects/09patt.html

This site provides links to the pattern headings, which was created by Library of Congress in 1974. These pattern headings are listed in three ways:

By Subject Field

By Category

By Heading

RLG Authority Assistant Saves Time for Catalogers

http://www rlg.org/r-focus/i38.authority.html

This site provides information on the RLG Authority Assistant. The Authority Assistant was introduced by the Research Libraries Group in February 1999 and expedites the creation of new authority records in the Name Authority File by allowing catalogers to select a heading from a bibliographic record in any RLIN Bibliographic file and use a new Generate command in the RLIN Cataloging function to create a basic authority record.

Social Security Death Index

http://www.ancestry.com/search/rectype/vital/ssdi/main.htm

This site provides link to the Social Security Death Index on the Internet. This database is free for Ancestry.com subscribers and guests. The database contains information provided by the Social Security Administration through the end of November 2001 and contains 67,214,037 names.

Subdivisions Not Further Subdivided by $\$ x$ History

http://www.tulane.edu/ techserv/subdhist.html

This link is taken from the Library of Congress Subject Cataloging Manual: Subject Headings, HI647, section 9. It gives directions on the use of \$x History after free-floating subdivisions.

Subject Cataloging: Free-Floating Subject Subdivisions http://www. itcompany.com/inforetriever/form_subdivisions_list.htm

Compiled by Vianne Sha at the University of Missouri-Columbia Libraries. This list 
includes guidelines on the usage of the LCSH free-floating form subdivisions. The guidelines are collected from the LC Subject Cataloging Manual. (From Internet Library for Librarians) "This document is no longer maintained as of December 13, 2000"-The web page.

Use of \#v Subfield for Form Subdivisions in Subject Headings

http://www.lib.usm.edu/ techserv/cat/formsubv.htm

This site provides a link to the List of Form Subdivisions implemented by Library of

Congress starting February 17, 1999. It is compiled by Kathleen L. Wells, Senior Catalog Librarian at University of Southern Mississippi Libraries.

Useful Subdivisions to Identify Primary Sources Materials (LCSH) http://www.library.yale.edu/ref/handouts/lcshprim.html

This site provides links to a list of useful subdivisions to identity primary sources materials.

\section{CATALOGING TOOLS BY TYPE OF MATERIALS}

This section is divided by type of material and under each type there are links to selected web sites that include information on cataloging.

\section{Books}

Book Cataloger's Cheat-Sheet http://www.music.Indiana.edu/tech_s/manuals/training/

marc/bookcheat.html

http://www.slc.bc.ca/cheat.htm

These are commonly used codes in book cataloging.

Cataloging Workflow, University of South Carolina

http://www.sc.edu/library/techserv/catalog/workflow.html

This resource includes workflow procedures for Monographic Copy Cataloging, In

Process Materials, New Materials and USC Theses Cataloging at the University of South Carolina Libraries.

Core Bibliographic Record for Books

http://lcweb.loc.gov/catdir/pcc/corebook.html

This is the Program for Cooperative Cataloging's (PCC) core bibliographic record for a book. 
IOCM: Processing of IUB Print Materials with Accompanying Cassette ${ }^{\wedge}$ )

http://www.indiana.edu/ libiocm/accompanying_cassettes.html

This web site links to processing of IUB (Indiana University Bloomington Libraries) Print Materials with Accompanying Cassette (s) at the IOCM (10 Catalog Management Department), Indiana University Bloomington Libraries.

\section{Foreign Language Materials}

This section provides selected tools for cataloging foreign language materials.

ALA-LC Romanization Tables

http://www.loc.gov/catdir/cpso/roman.html

This site links to the 1997 edition of the ALA-LC Romanization Tables. It contains 54 romanization and transliteration schemes for Non-Roman Scripts. The Library of Congress and the American Library Association approved these tables. These links are to PDF files that require the Adobe Acrobat Reader.

Babel Fish (AltaVista Translations)

http://babelfish.altavista.com/translate.dyn

This is an AltaVista translation tool and it provides translation to documents to or from English, French, German, Italian, Portuguese, Spanish, Russian, Japanese, Korean and Chinese.

Cataloging Foreign Language Materials http://filebox.vt.edu/admin/international/resdev/catalog.html

This site contains links to aids for cataloging foreign materials. For example, it has a section on issues in cataloging Non-Western Materials: special problems with African language materials.

Chinese Character Pronunciations

http://www.ocrat.com/reaf/

This site provides a transliteration tool for Chinese characters; provides the transliterated pronunciation of each Chinese character.

Foreign Languages Aids

http://tpot.ucsd.edu/TSU/foreign.html

This web site provides comprehensive links to foreign language tools such as:

Abbreviations in Latin Inscriptions, Alphabet Street: Transliterations and Special 
Characters, Alternative Dictionaries, ARTFL Project (University of Chicago), BabelFish (translator), Cataloging Foreign Language Materials, Chinese Character Pronunciations, Japanese Library and Information Science, Spanish Subject Headings (Oakland Public Library). It provides a brief description for each resource.

Free Translation.com.

http://www.freetranslation.com/

This is an easy-to-use site for rapid translations from English to Spanish, French,

German, Portuguese, Italian, and Norwegian.

Glossary of Bibliographic Information by Language

http://www.mun.ca/library/cat/lang/biblang.htm

http://130.15.161.74/techserv/biblang.html

These sites list bibliographic information by language.

Google's Language Tools

http://www.google.com/language_tools?hl=en

This site links to Google's language tools. Users can search by language, country, and translate a text or web page.

Initial Article in Foreign Languages

http://libweb.uoregon.edu/orbis/staffhome/titles.init_articles.htm

This Site provides information on initial articles in foreign languages. Orbis Library

Consortium, Northwest Academic Library Connection, created this link and it is based on

ALA Filing Rules, published by American Librarian Association, Chicago, c1980.

Issues in Cataloging Non-Western Materials: Special Problems with African Language Materials http://filebox.vt.edii/cidmin/international/resdev/africana.html

This site provides links to issues in cataloging of non-Western materials. The emphasis is on problems related to African language materials. It was created by Cynthia D.

Bertelsen. October 8, 1995.

Language Identifier

These sites help to identify the language of origin of foreign words.

XRCE Language Identifier

http://yvww.xrce.xerox.com/research/mltt/tools/guesser/

The Xerox XRCE language identifier recognizes 47 different languages. 
Language Guesser Demo

http://odur.let.rug.nl/ vannoord/TextCat/Demo/textcat.html

The TextCat language identifier recognizes 77 different languages.

Stochastic Language Identifier

http://www.dougb.com/ident.html

The Stochastic language identifier recognizes 13 different languages.

Mezzofanti Translations

http.//www.mezzofanti.org/translation/

The most useful translation site on the Internet. From this site users have access to translators on the Internet. It is a free service and there are links to other foreign dictionaries and translators.

Slavic Cataloging Manual

http://www.indiana.edu/ libslav/slavcatman/slindex.html

http://infosharel.princeton.edu/katmandu/sgman/AAASS.html

These web sites provide the best cataloging manual for Slavic materials. James L.

Weinheime created the one at Princeton in September 1998 and completed the one at Indiana in July 2001.

\section{Government Publications}

Basic Depository Library Documents: The Unauthorized HTML Editions http://www.du.edu/bdld/

This resource provides links to the basic Federal Depository Library Program documents of the University of Denver. Coded and designed by Thomas G. Tyler.

Catalog of U.S. Government Publications

http://www.access.gpo.gov/su_docs/locators/cgp/index.html

"The Catalog is a search and retrieval service that provides bibliographic records of U.S. Government information products. Use it to link to Federal agency online resources or identify materials distributed to Federal Depository Libraries. Coverage begins with January 1994 and new records are added daily. New Electronic Titles contains online titles that are the latest entries in the Catalog or are in the queue to be added to it."-The web site.

FDLP Desktop/Federal Depository Library Program (U.S.)

http ://www.access.gpo.gov/su_docs/fdlp/index.html 
This site provides links to information on the FDLP, depository management, electronic collection, locator tools and services, processing tools, publications, and questions and answers.

Government Documents Cataloging. UCLA Cataloging Web Pages

http://www.library.ucla.edu/lihraries/cataloging/referenc/govdocs.htm

This site links to the Toolbox for Processing and Cataloging Federal Government Documents, FDLP Handbooks, Manuals, and Guides, GPO Cataloging GuidelinesComputer Files No. 1A, GPO Cataloging Guidelines-Collection-Level Records, GPO Cataloging Guidelines-Linking Fields No. 1.

Government Document Depository Tools. Colby College Library, Technical Service Department http://www.colby.edu/lihrary/collections/technical_services/wp/GovtDocTools.shtml

A very useful web site that includes links to valuable information related to the GPO, such as shipping lists, list of classes and related files, FDLP handbooks, manuals and guides, associations, listservs, publishers, and cataloging guidelines. Created by Margaret Menchen.

GPO Access

http://www.access.gpo.gov/su_docs/

"GPO Access is a service of the U.S. Government Printing Office that provides free electronic access to a wealth of important information products produced by the Federal Government ."-The web site.

GPO Cataloging Guidelines

http://www.access.gpo.gov/su_docs/fdlp/cip/index.html

This site provides access to the Federal Depository Library Program (FDLP) Cataloging Guidelines in MS Word and as a PDF file.

GPO PURL Alert

http://www2.lib.udel.edu/godort/cataloging/alert/

This service issued by the GODORT (Government Documents Round Table) Cataloging Committee to assist libraries wishing to add PURLs to GPO records already in their catalogs. "Beginning in January 2000, the GPO PURL Alert provides monthly lists of GPO Cataloging records which have had PURL information added to the 856 field. Using GPO PURL Alert lists in electronic format allows libraries to cut and paste the PURLs into their local catalogs."-Title screen (From Internet Library for Librarians).

How to Read SuDoc Numbers 
http://www.hanover.edu/Library/Reference/SuDoc.html

This site provides direction on how to read and find a SuDoc number.

SuDocs Letter to Directors: Changes in FDLP

http://www.access.gpo.gov/su_docs/fdlp/coll-dev/sdltr8-25-00.html

A resource listing the content of the SuDocs letter from Frances J. Buckley, Jr., Superintendent of Documents, Federal Depository Library Program (FDLP) to library directors.

Superseded List for U.S. GPO Materials

http://www.access.gpo.gov/su_docs/fdlp/pubs/suplist/index.html

The Superseded list for U.S. Documents that may be discarded by depository libraries annotated for retention by regional depositories. The list is organized by year.

Toolbox for Processing and Cataloging Federal Gov Doc

http://www2.lib.udel.edu/godort/cataloging/toolbox.htm

This is a very comprehensive web site that brings together tools and guides for both new and experienced library staff who process and catalog depository materials. Created and edited by John A. Stevenson and the Cataloging Committee of the American Library Association's Government Documents Round Table.

\section{Internet/Electronic Resources}

This section provides links to cataloging electronic resources tools. The resources are organized under three groups: General Resources, Maintaining URL, and Licensing Resources.

\section{General Resources}

ALA Committee on Cataloging: Description and Access: Task Force on Metadata and the Cataloging Rules. Final Report August 21, 1998

http://www.ifla.org/VII/sl3/pubs/isbd-let.htm

This site provides a link to the Task Force on Metadata and the Cataloging Rules' Final Report presented to ALCTS.

Cataloging Internet Resources, A Manual and Practical Guide edited by Nancy B. Olson, 1995

http://www.oclc.org/oclc/man/9256cat/tocfr.htm

This site provides a link to the "Cataloging Internet Resources" manual. 
Cataloging Internet Resources Workshop

http://www.fis.utoronto.ca/inforum/cir/

A home page for a "Cataloguing Internet Resources" workshop given at the Faculty of Information Studies, University of Toronto. It provides some interesting items concerning cataloging Internet resources. Instructor: Joe Cox.

CATNET Project (University of Arizona)

http://dizzy.library.arizona.edu/users/eagleson/catnet-w.htm

This site includes links to the University of Arizona's CATNET project. It includes the charge of the committee and the final report.

Center for Electronic Texts in the Humanities (CETH). Directory of Electronic Text Centers http://harvest.rutgers.edu/ceth/etext_directory/

This site provides a directory of electronic text centers in and outside of the USA. The directory is organized in alphabetical order and includes links to each center. Compiled by Mary Mallery.

Connexion

http://www.oclc.org/connexion/

Connexion is the new face of OCLC cataloging, providing one-stop access to integrated cataloging tools and to WorldCat, the world's largest online union catalog and bibliographic database. This web site provides information on the new OCLC cataloging interface, questions and answers, and how to use it.

CONSER Cataloging Manual: Module 31-Remote Access Electronic Serials

http://lcweb.loc.gov/acq/conser/module31.html

This site provides a link to the content of the CONSER Cataloging Manual Module 31 -

Remote Access Electronic Serials.

CONSER Cataloging Manual: Module 33.18-Electronic Newspapers

http://lcweb.loc.gov/acq/conser/enewsppr.html

This site provides a link to the content of CONSER Cataloging Manual, module 33.18 for electronic newspapers.

CONSER Working Group: Single or Separate Record: What's Appropriate and When? http://wwwtest.Library.ucla.edu/libraries/cataloging/sercat/conserwg/

This is a link to the Working Group page that includes the charge, background, timeframe, and lists the members of the Working Group.

Dublin Core Metadata Initiative 
http://dublincore.org/

This site provides a link to the Dublin Core Metadata Initiative, Documents, Tools and Software, Meetings, Group, Discussion, Projects, and Resources.

Guidelines for Cataloging Internet Resources by Vianne Sha http://www.itcompany.com/inforetriever/catinpol.htm

This site discusses the priorities and policies of cataloging Internet resources.

Guidelines for Coding Electronic Resources in Leader/06. Network Development and MARC 21 Standards Office, Library of Congress http://lcweb.loc.gov/marc/ldr06guide.html

This site provides a link on how to code records for electronic resources in Leader/06 (Type of record) and Computer Files 008/26 and 006/09 (Type of computer file).

Guidelines for the use of Field 856. Network Development and MARC Standards Office, Library of Congress

http://lcweb.loc.gov/marc/856guide.html

This site links to the guidelines on the use of field 856 and is current as of July 1999. It includes all changes to the field through the annual ALA conference held in June 1999.

IFLA (International Federation of Library Associations and Institutions) Cataloging and Indexing of Internet Resources

http.//www.ifla.org/II/catalog.htm

This site includes links to both digital library resources and projects and traditional cataloging resources.

Index Morganagus

http.//sunsite.berkeley.edu/IndexMorganagus/

Full text searchable index of library-related electronic serials.

Innovative Internet Application in Cataloging

http://www.wiltonlibrary.org/innovate.html

A site that provides a link to some useful Internet resources.

Interactive Electronic Serials Cataloging Aid

http//staffweb.library.northwestern.edu/serials/iesca/

"This interactive training tool has been developed at Northwestern University Library to 
instruct serial catalogers how to catalog electronic serials. This tool is primarily provides ready access to cataloging rules, interpretation, examples of MARC bibliographic records in serial and computer files formats linked to instructional annotations, and a glossary of cataloging and computer terminology."-The Web Site

ISBD (ER): International Standard Bibliographic Description for Electronic Resources http://www.ifla.org/VII/sl3/pubs/isbd.htm

This site provides a link to the ISBD for electronic resources. It is revised from the ISBD (CF): International Standard Bibliographic Description for Computer Files and recommended by the ISBD $(\mathrm{CF})$ Review Group-From IFLANET web page.

MARCit-Nichols Advanced Technologies Inc.

http://www.marcit.com/

A tool for cataloging the Internet, MARCit automatically grabs the site's title and URL from the Web browser, catalogs the title, system details, and URL fields.

Organizing Internet Resources: Non-Cataloging Approach

http://www.itcompany.com/inforetriever/catinetl.htm

This site provides useful links to resources related to organizing Internet resources. The resources are organized under these sections: General Resources, Cataloging and Digital Projects, Databases, Dewey Decimal Classification (DDC) Approach, Library of Congress (LC) Approach, and Metadata.-From Internet Library for Librarians web site.

Serials in Cyberspace: Collections, Resources, and Services http://www.uvm.edu/ btnaclenn/

This site provides links to selected sites with electronic journal, selected E-journal titles, associations, societies, organizations, programs, etc. (includes ISSN information), and other useful sources (not E-journal specific).

\section{Maintaining URLs Tools}

PURL

http://purl.oclc.org/

This site provides link to the OCLC PURL (Persistent Uniform Resource Locator) service which is used for the URL resolution.

GPO PURL Alert

http://www2.lib.udel.edu/godort/cataloging/alert/ 
This service was issued by the GODORT (Government Documents Round Table) Cataloging Committee to assist libraries wishing to add PURLs to GPO records already in their catalogs. "Beginning in January 2000, the GPO PURL Alert provides monthly lists of GPO Cataloging records which have had PURL information added to the 856 field. Using GPO PURL Alert lists in electronic format allows libraries to cut and paste the PURLs into their local catalogs."-Tifle screen (From Internet Library for Librarians).

Naming Conventions for Digital Resources

http://lcweb.loc.gov/marc/naming.html

This paper is a general summary of developments concerning naming conventions for digital resources. In particular, attention is given to the standards developed by the Internet Engineering Task Force, Uniform Resource Identification (URI) Working Group, and naming conventions/systems used in the library community, such as LC, OCLC, RLG. From Internet Library for Librarians.

\section{Licensing Resources}

Checklist for Review of License Agreement, University at Buffalo Libraries http://ublib.bujfalo.edu/libraries/units/cts/about/ license_check.html

This site includes the policy of the University at Buffalo Libraries to review licenses for all electronic titles and products, Availability of License Agreements, License Terms, and a Procedure for Making Changes to License Terms.

\section{CNI-Copyright}

To subscribe send a message to: listproc@arl.org

CNI-Copyright is an open, public electronic forum for discussion of a broad range of copyright and intellectual property related issues. The text of the message should read: subscribe cni-copyright [your name].

Contract Title: Terms and Conditions for Electronic On-Line Databases http://www.ogs.state.ny.us/purchase/snt/awardnotes/79100.htm

This document contains the Terms, Conditions, and License Agreement that will apply to the contracts listed for access to electronic on-line databases and other on-line information subscription services.

Copyright and Fair Use. Stanford University Libraries http://fairuse.stanford.edu/ 
This site contains a comprehensive set of documents and links related to libraries, copyright, and fair use.

Copyright and Intellectual Property. Association of Research Libraries

http://www.arl.org/info/frn/copy/copytoc.html

This site includes a range of materials including statement of principles, analyses of legislation and court decisions, as well as links to other sites.

ICOLC (International Coalition of Libraries Consortia) Statement of Current Perspective and Preferred Practices for the Selection and Purchase of Electronic Information http.//www library.yale.edu/consortia/statement.html

The International Coalition of Library Consortia (ICOLC) statement sets forth concerns about the current electronic information problems and the needs for the future, preferred practices in the emerging electronic information environment.

IFLA Publications Licensing Principles

http://www.ifla.org/V/ebpb/copy.htm

IFLA (The International Federation of Library Associations and Institutions) presents a set of basic principles that should prevail in the contractual relationship and written contracts between libraries and information providers. It was prepared by IFLA's Committee on Copyright and other Legal Matters (CLM). Topics include: licenses and the law, licenses and values, licenses: access and use, licenses and end users, licenses and perpetual access, licenses and pricing, interlibrary loan, teaching and learning.

Let There be Light. Licensing Electronic Resources: State of the Evolving Art, Summary of Proceedings

http://www.arl.org/scomm/licensing/sum.html

This is a summary of the program co-sponsored by the Association of Research Libraries (ARL), Office of Scholarly Communication and the Coalition for Networked Information and held December 8-9, 1996, in San Francisco. It focuses on the complex issues involved in licensing electronic information resources from the perspective of librarians, lawyers, publishers, providers, and information technologists. By George Soete, ARL/OMS Organizational Consultant.

Lib License: Licensing Digital Information, a Resource for Librarians http://www.library.yale.edu/ llicense/index.shtml

This is a web site and a discussion list created by The Yale University Library, Commission on Preservation \& Access, and the Council on Library Resources.

LIBLICENSE-L Mailing List 
http://www.library.yale.edu/ llicense/mailing-list.shtml

Liblicense-L List Archives

http://www.library.yale.edu/ llicense/ListArchives/

Licenses Provided by Publishers

http.//www.library.yale.edu/ llicense/publishers.shtml

This page is under construction. It will contain links to texts of actual licenses supplied by the kindness of publishers already doing business with electronic texts such as EBSCO and JSTOR.

Licensing Electronic Resources: Strategic And Practical Considerations for Signing Electronic Information Delivery Agreements

http://www.arl.org/scomrn/licensing/licbooklet.html

This is a link to the strategic and practical considerations for signing electronic information delivery agreements. It also includes sections on copyright issues and copyright vs. license. Prepared by Patricia Brennan, Karen Hersey, and Georgia Harper.

Licensing Issues

http://www.arl.org/scomm/licensing/

This ARL web site includes basic and advanced licensing workshops, publishers' workshop: Licensing Electronic Resources to Libraries.

Licensing Resources, University of Texas System

http://www.utsystem.edu/ogc/intellectualproperty/licrsrcs.htm

This site contains a range of resources related to copyright in the library. It includes an interactive Software and Database License Agreement Checklist.

Licensing Terms and Descriptions

http://www.library:yale.edu/ llicense/table.shtml

This is from the Licensing Digital Information web site. "The topics consist of clauses that generally appear in licensing agreements. Each topic consists of a discussion of the general issues raised by the subject, as well as some general advice to consider when negotiating the particular clause. Following the general discussion are examples of specific contract language relating to the topic that have appeared in actual licensing agreements, along with a discussion of the examples."-The web site.

Managing the Licensing of Electronic Products: SPEC FLYR 248 http://www.arl.org/spec/248fly.html

This is the result of the SPEC survey on how research libraries have organized the 
licensing of electronic products and how they approach the associated problems. The SPEC survey program gathers information from ARL member institutions on current research in library practices and policies.

Negotiating Networked Information Contracts and Licenses

http://www.cni.org/projects/READl/guide/

"This guide, sponsored by the Coalition for Networked Information offers a paragraphby-paragraph analysis of contractual language in the networked environment. It is designed to assist network vendors, suppliers, publishers, and buyers of networked information in their efforts to negotiate effective agreements."-The website. It includes a section on the structure of each entry, defining the product or service, parties to the agreement, defining the user, buyer uses, use restrictions, methods of use, passwords, reports, compliance, liabilities, warranties, disputes, backup, term/termination/extensions, copyright notice, trademarks, assignments, technical specifications, training and documentation, support services, data integrity, and payment. Prepared by Robert Ubell and Mark Tesoriero, 1994.

Principles for Acquiring and Licensing Information in Digital Formats. University of California Libraries, Collection Development Committee, 1996

http://www.indiana.edu/ libsalc/policies/ucal.html

This list of principles is provided to guide the University of California and its employees (at both campus and system wide levels) in developing and reviewing proposals to/from, and in negotiating contracts with, providers of information in digital formats.

Principles for Licensing Electronic Resources. Final Draft, 1997

http://www.arl.org/scomm/licensing/principles.html

This is a combined effort between the American Association of Law Libraries, American Library Association, Association of Academic Health Sciences Libraries, Association of Research Libraries, Medical Library Association, and Special Libraries Association to develop a statement of principles for licensing electronic resources. These six associations represent an international membership of libraries of all types and sizes. The intent of this document is to guide libraries in negotiating license agreements for access to electronic resources, and to provide licensors with a sense of the issues of importance to libraries and their user communities in such negotiations.

Music

All Music Guide

http://www.allmusic.com/

This is a guide to music styles, articles, books, glossary, and CDs.

Cataloging MP3s: the Sound of Things to Come? 
http://wings.buffalo.edu/publications/mcjrnl/v7n2/freebornmp3.html

This is about cataloging MP3s and it includes some examples. By Robert Freeborn.

Core Bibliographic Record for Music and Non-Music Sound Recordings

http://lcweb.loc.gov/catdir/pcc/coremusic.html

This is the Program for Cooperative Cataloging (PCC) guideline for the core

bibliographic records for Music and Non-Music Sound Recordings.

Core Bibliographic Standard for Scores

http://lcweb.loc.gov/catdir/pcc/coremusmss.html

This is the Program for Cooperative Cataloging (PCC) guideline for the core bibliographic records for scores.

Cutter Table for Music Composers

http://www.mun.ca/library/cat/tables/composer.htm

This list is prescriptive for Cutter numbers to be used for particular composers when cataloguing scores in the "M" classification.-Cat-aloger's Toolbox web site.

Cylinder, Disc and Tape Care in a Nutshell

http://lcweb.loc.gov/preserv/care/record.html

This Library of Congress site carries preservation guidelines on handling, storage, cleaning, packaging, playback equipment maintenance, and bibliography.

Guide to Copyright for Music Librarians

http://www.musiclibraryassoc.org/Copyright/copyhome.htm

This web site contains links to the latest, recent, and current news and developments in issues related to copyright. It also includes section on frequently asked questions, related Internet resources, and bibliography. Sponsored by the Legislation Committee of the Music Library Association.

Guidelines for Sheet Music Cataloging http://www.lib.duke.edu/music/sheetmusic/title.html

This is an experimental page to test World Wide Web access to the draft guidelines for sheet music cataloging. These recommendations have not yet been accepted by the Music Library Association, Bibliographic Control Committee.

Handbook of Examples for Use in Authority Records http://www.library.yale.edu/cataloging/music/nmp_hdbk.htm 
This handbook is a compilation of examples with explanations for creating citations for sources of information in the authority record. Created by the NACO-Music Project Michelle Koth, Yale University Music Library.

Indiana University Music Library

http://www. music.indiana.edu/tech_s/manuals/ts.htm

This was prepared by the Music Library Technical Services Division, Indiana University and includes links to manuals, documentation and reference sources.

Instrument or Voice Codes for 048

http://www.mun.ca/library/cat/tables/048.htm

This site contains the instrument or voice codes for use in MARC 21 Bibliographic Formats field 048.

International Standard Music Number User's Manual http://www.nlc-bnc.ca/ismn/sl2-200-e.html

This web site provides links to the International Standard Music Number user's manual.

Music Cataloging at Yale

http://www.Ubrary.yale.edu/cataloging/music/musicat.htm

This is a comprehensive web site and it includes information on call numbers, music cataloging resources, uniform titles, NACO, AACR2, subject cataloging, MARC 21 tagging, bindery and marking, ORBIS, Voyager, and RLIN, language tools, biographical sources, other music cataloging web sites, online catalogs, WorldCat, New Grove, 2nd ed. (Yale IP addresses only).

Music Library Association (MLA) Clearinghouse

http://www.music.indiana.edu/tech_s/mla/index.htm

The MLA Clearinghouse stores documents of interest to music librarians.

Music Library Association (MLA): Useful Resources Online http://www.musiclibraryassoc.org/useful/use.htm

This resource provides links to Music Library Association electronic discussion group, MLA related web sites, and links to other professional organizations.

Music Library Technical Services Division, Manuals, Documentation, Reference Sources, etc. http://www.music.indiana.edu/tech_s/manuals/ts.htm

This site includes general tools for cataloging music materials. 
Obituary Index

http://www-sul.stanford.edu/depts/music/mla/necrology/welcome.html

This web site provides a link to the on-line version of an index of obituary citations published annually by the Music Library Association (MLA) in its quarterly journal, Notes. The index facilitates access to information about musicians and other members of the music world.

Principles of Music Uniform Titles

http://www.music.indiana.edu/tech_s/mla/ut.gui

This site includes some principles of music uniform titles which have been derived from the AACR2, chapter 25. By Matthew W. Wise.

Reference Sources for Use in Cataloging Sheet Music

http://www.lib.duke.edu/music/sheetmusic/sources.html

This bibliography was prepared for the Sheet Music Round Table at the 1998 Annual Meeting of the Music Library Association. By John Bewley, Mickey Koth, and Lois Schultz.

Score Cataloger's Cheat-Sheet http://www. music.Indiana.edu/tech_s/manuals/training/marc/ scorecheat.html

These are commonly used MARC 21 codes in scores cataloging.

Sheet Music Cataloging Guidelines/Bibliographic Control Committee of MLA http://www.lib.duke.edu/music/sheetmusic/sheetmusic.html

At the 1992 annual meeting of the Music Library Association some individuals discussed developing a set of guidelines to facilitate cataloging collections of sheet music. A Working Group on Sheet Music Cataloging Guidelines was formed under the direction of the Bibliographic Control Committee. The Working Group was chaired by Lois Schultz. This web site contains a link to the description of Sheet music (AACR2 Chapter 5). "The recommendations in these guidelines have not yet been accepted by the Music Library Association, Bibliographic Control Committee."-The web site.

Thematic Index Used by the LC for Formulating Uniform Titles for Music as Listed in the Music Cataloging Bulletin http://www.music.indiana.edu/tech_s/mla/themlist.96

This site includes the Thematic Index Used by the LC for Formulating Uniform Titles for 
Music as Listed in the Music Cataloging Bulletin. Prepared by Lois Kuyper-Rushing.

Types of Compositions for Use in Music Uniform Titles

http.//www.library.yale.edu/cataloging/music/types.htm

A Manual for Use with AACR2 Chapter 25 2nd, Updated Edition, June 1997 Revised 2002. Final Report of the Working Group on Types of Compositions. It includes links to the introduction of the $2 \mathrm{nd}$, updated edition, preface to the 1st edition, additions and changes to this document, principles of the list, diacritics, use of "double," "triple," etc., in titles of musical works, submitting terms for consideration, and direction on ordering a print copy of the list.

Worldwide Internet Music Resources

http://www.music.indiana.edu/music_resources/

This site contains links to worldwide Internet music resources and is offered as a service of the William and Gayle Cook Music Library, Indiana University School of Music.

\section{Other Non-Print Materials}

Cataloging CD-ROMs and Computer Disks

http://infosharel.princeton.edu/katmandu/comp/comfil.html

This web site provides guidelines for cataloging CD-ROM and computer disks from

Princeton University Library's Cataloging Documentation.

Cataloging Microforms, Photocopies, and Reprints (Princeton)

http://infoshare1.princeton.edu/katmandu/micro/mictoc.html

http://infoshare1.princeton.edu/katmandu/phystrea/phytoc.html

These are excellent guidelines for cataloging microforms, photocopies, and reprints at the

Princeton University Library. The guidelines includes definitions, how to determine cataloging treatment of a microform or photocopy, cataloging instructions, holding screen, multiple version, and examples of 533 Notes and \$7.

Cataloging of Microfilm Copy at Minimal Level (Yale)

http://www.library.yale.edu/cataloging/artsciteam/dismic.html

This site includes a guideline for cataloging microfilm copy at minimal level at Yale

University Library. Examples are given.

Cheat Sheet-A "Bare Bones" Guide to Cataloging Photographs http:/www.slais.ubc.ca/people/students/student-projects/C_Schultz/

L513Zbones.html 
This is a step-by-step guideline to cataloging photographs.

Computer File Cataloging Cheat-Sheet

http://library.uncwil.edu/techserv/computerfilesheet.htm

This is a step-by-step guideline to cataloging computer file/interactive multimedia.

Films and Videos

http://www.library.unass.edu/catalog/nonb.html

This is a comprehensive page of information on cataloging $\mathrm{A} / \mathrm{V}$. This page includes information on the following: AMIA (Association of Moving Image Archivists); Archival Moving Image Materials-A Cataloging Manual; AV Authority Tools for Catalogers: An Annotated List of Useful Resources; Booklist: Audiovisual Media; Care, Handling and Storage of Motion Picture Film; Core Bibliographic Record for Audio Visual Materials Task Group; Core Bibliographic Record for Moving Image Materials (Final); Internet Movie Database; Latin American Video Archives; NACO AV-Funnel Project; National Captioning Institute; NICEM.com-Natl. Info. Center for Educational Media; Original Cataloging Guide for Video Recordings (U. of FLA); Policy on Classification of Feature Film Video recordings (USM); Proposed RIs Concerning Uniform Titles for Video Cataloging; Retrospective Conversion Cataloging of $\mathrm{Au}$ diovisual Materials at Penn State University's Education Library; TV Guide's Movie Database; Video Cataloguing Cheat Sheet; Video Librarian; Videocassette Cataloging Checklist (Yale).

Guidelines for Cataloging Microforms (CATPRO) (University of Florida) http://web.uflib.ufl.edu/rs/catpro/microcatonly.html

This site is from the Cataloging Manual of the Resource Services Department, University of Florida and it contains guidelines for cataloging microforms.

Microform Cataloging Cheat Sheet (for Microfiches, Microfilms)

http://library.uncwil.edu/techserv/microformsheet.htm

This web site includes the basic fields for cataloging microforms.

Online Audiovisual Catalogers (OLAC)

http://ublib.bujfalo.edu/libraries/units/cts/olac/about.html

The Online Audiovisual Catalogers Web Page (OLAC) provides a means for exchange of information, continuing education, and communication among catalogers of audiovisual materials and with the Library of Congress. It includes links to conferences, NACO/AV, newsletters, book reviews, useful web sites for $\mathrm{A} / \mathrm{V}$ catalogers, and other related information. 
Useful Web Sites for A/V Catalogers

http://ublib.buffalo.edu/libraries/units/cts/olac/websites.html

This web site is from the Online Audiovisual Catalogers (OLAC). It provides links to many useful resources for $\mathrm{A} / \mathrm{V}$ catalogers.

\section{Rare Books}

Core Standard for Rare Books (DCRB Standard)

http://lcweb.loc.gov/catdir/pcc/dcrbcore.html

This site includes a link to the Program for Cooperative Cataloging (PCC), Core

Bibliographic Records for Rare Books.

DCRB (Descriptive Cataloging of Rare Books) Core Task Group Final

Report

http://lcweb.loc.gov/catdir/pcc/dcrbreport.html

This site includes the DCRB Core Task Group final report, November 1998.

Descriptive Cataloging of Rare Books (DCRB), 2nd Edition: Contents

http://www.tlcdelivers.com/tlc/crs/rareOl70.htm

This web site contains the descriptive cataloging rules for rare books. In addition, includes several appendixes on title access points, early letter forms, rare serials, minimal-level records, DCRB code for records, concordance between rules in DCRB and AACR2, and glossary.

Directory of Web Resources for the Rare Materials Cataloger http://oldsite.library.upenn.edu/ipc/rarecat.html

This site is prepared by ACRL, Rare Book and Manuscripts Section, and Bibliographic Standards Committee. It includes very useful links to cataloging rare books and special collections materials.

Special Cataloging Team. Penn State University Libraries-Cataloging Department http://www.libraries.psu.edu/iasweb/catsweb/rarebook/index.htm

This site includes cataloging tools and procedures for cataloging rare materials.

The Rare Materials Cataloger's HelpNet-Online Consultation in the Cataloging of Rare Books, Manuscripts \& Special Materials 
http://www.library.yale.edu/bibstand/resource.html

This site is prepared by ACRL, Rare Books and Manuscripts Section, and Bibliographic Standards Committee. It provides links to experienced rare materials catalogers who have volunteered to respond to queries in their areas of expertise. The site is organized by five general areas of expertise: Systems, Material Type/Genre, Subject, Periods, and Languages.

RBMS (Rare Books and Manuscripts Section) Thesauri for Use in Rare Book and Special Collections Cataloging http://libweb.uoregon.edu/catdept/home/genreterms/main.html

This site includes a link to where to purchase the six thesauri which were developed for use in MARC 21 fields 655 and 755 (now obsolete; all terms are now used in field 655). Each thesaurus provides standardized vocabulary for retrieving items by form and genre or by various physical characteristics that are typically of interest to special collections librarians.

Resources for the Rare Materials Cataloger

http://oldsite.library.upenn.edu/ipc/rarecat.html

This is a comprehensive site for rare book cataloging. It includes: General Cataloging Sites, Rare Book Cataloging Sites and Resources, Library of Congress Lists, Reference Sites-General-Language Resources-Biography Sites-Place Names-Calendars and Computus, Special Collections Sites, History of Books and Printing, Special Topics for Rare Books, Images of Rare Books. It also includes a section relating to cataloguing medieval manuscripts.

\section{Serials}

AACR2 and Seriality

http://lcweb.loc.gov/acq/conser/serialty.html

This site provides a link to the AACR Review Task Force, the Group Reports, Proposal to Adopt a Modified Model C, Graphical Model of the Bibliographic Universe (Modified Model C), Incorporating Entry: a New Concept for Cataloging Electronic Journals, Establishing a Benchmark to Determine When to Make a New Serial Record, ISSN and Seriality, Proposal for a Succession of Latest Entry Records, Revising AACR2 to Accommodate Seriality: Report to the JSC.

ACQWEB's Directory of Publishers and Vendors http://acqweb.library.vanderbilt.edu/acqweb/pubr.html

This site provides a link to AcqWeb, an international directory of publishers and vendors used by libraries. It links to their Web sites and email addresses. It is useful for 
acquisitions, collection development and serial librarians.

All that JAS: Journal Abbreviation Sources

http://www.public.iastate.edu/ CYBERSTACKS/JAS.htm

"All That JAS: Journal Abbreviation Sources is a registry of web resources that list or provide access to the full titles of journal abbreviations."-The web site.

CONSER Editing Guide, 1994 Edition: Contents

http://www.tlcdelivers.com/tlc/crs/edit7375.htm

This site includes an introduction to the 1994 Edition, Section A. the CONSER Program: Background and Organization, Section B. Policies and Agreed-Upon Practices, Section C. Procedures and Instructions, Section D. Introduction to Format, Section E. MARC 21 Format for Serials as Applied within CONSER, Section F. Appendices, and Index. From the Cataloger's Reference Shelf (http://www.tlcdelivers.com/tlc/crs/crsOOOO.htm).

CONSER Cataloging Manual: Contents

http://www.tlcdelivers.com/tlc/crs/manll573.htm

This guide covers: Part I. Original Cataloging, Part II. Adapting Records, Part III. Special Problems and Types of Serials, Appendices, and Index-From the Cataloger's Reference Shelf (http://www.tlcdelivers.com/tlc/crs/crsOOOO.htm).

CONSER Publication Pattern Coordinated by the CONSER Task Force on Publication Patterns and Holdings http://www.locgov/acq/conser/patthold.html

This is a link to the CONSER Publication Pattern Initiative, which offers the Guidelines for Input of Captions/Patterns and Holdings.

Revising AACR2 to Accommodate Seriality

http://www.nlc-bnc.ca/jsc/ser-repO.html

This web site provides a link to the Revising AACR2 to Accommodate Seriality report presented to the Joint Steering Committee for Revision of AACR by Jean Hirons et al.

SCCTP (Serials Cataloging Cooperative Training Program (CONSER)

http://www.loc.gov/acq/conser/scctp/

This is a link to the Serials Cataloging Cooperative Training Program prepared by the CONSER Program. The Serials Cataloging Cooperative Training Program (SCCTP) provides authoritative training materials and trained serials experts to enable broad-ranging education in the field of serials cataloging. 
Serials Cataloging Issues, CONSER (Cooperative Program for Serials

Cataloging)

http://www.loc.gov/acq/conser/issues.html

This site provides a link to serial cataloging issues related to the CONSER Editing Guide, Preliminary Updates Related to the Restructured LCCN, Pinyin Conversion Guidelines for CONSER Participants, Guidelines for Cataloging Online Versions of Serials, Single or Separate Records: What's Appropriate and When, and other issues.

Serials Format Cheat Sheet for Fixed Fields

http://www.libraries.psu.edu/iasweb/techserv/ser/ffnearcopy.htm

This web site includes information related only to serial fixed field for copy and original cataloging.

Serial Record Division (Library of Congress)

http://lcweb.loc.gov/acq/srd/

This site provides information on the Serial Record Division at the Library of Congress.

Serial Holding Codes for Newfoundland Union List of Serials

http://www.mun.ca/library/cat/tables/serialcodes.htm

This site contains the old holding code, unicorn display, and the full name.

SERIALST Archive

http://www.uvm.edit/ bmaclenn/serialst.html

SERIALST (Serials in Libraries Discussion Forum) is an informal electronic forum for most aspects of serials processing in libraries. Appropriate topics include (but are not limited to): cataloging, acquisitions, collection management, serials budgets and pricing concerns, binding, preservation, microfilm and other nonprint serials media, union list activities, announcements, news, and job postings that are of interest to the serials community.

SICI: Serial Item and Contribution Identifier Standard: ANSI/NISO http://sunsite.berkeley.edu/SICU

"The SICI standard provides an extensible mechanism for the unique identification of either an issue of a serial title or a contribution (e.g., article) contained within a serial, regardless of the distribution medium (paper, electronic, Microform, etc.)."-The web site. This web page provides a link to SICI Version 2 final.

Tools for Serials Cataloging http://www.library.vanderbilt.edu/ercelaww'serials.html 
This web site links to a collection of useful sites and resources. It includes: Cataloging Documentation, Reference Sources, Library Catalogs, Serials Organizations, Serials Cataloging Cooperative Training Program, E-Mail Addresses for Cataloging Questions/ Problems, Electronic Journals/Newsletters/Citation Sources, Discussion List Archives, Other Sources, and Internet Search Engines.

U.S. ISSN Center

http://lcweb.loc.gov/issn/issnhome.html

This site provides links to the ISSN and Serials Publishing, ISSN Application Forms, ISSN International Network, American ISSN Friends (AmIS), and other Related Web Resources.

\section{Theses and Dissertations}

About Electronic Theses and Dissertations

http://etext.lib.virginia.edu/ETD/about/

This site includes articles, reports, and other items of note.

Cataloging OSU (Ohio State University Libraries) ETDs (Electronic Theses and Dissertations) http://www.lib.ohio-state.edu/catweb/etd.htm

This web site is a guideline for cataloging electronic theses and dissertations.

Creating a Partnership in Support of Students' Scholarship: The Electronic Thesis and Dissertation Project at University of Iowa

http://www.ala.org/acrl/papers01/welburn.pdf

A paper presented at the ACRL Tenth National Conference. By Janice SimmonsWelburn ... 2001.

Dissertations and Theses.com

http://www.dissertationsandtheses.com/

This web site provides a searchable database of research papers. It is a useful tool for graduate and post-graduate students conducting difficult research for their theses and/or dissertations. This database includes more than 25,000 quality research papers, experimental studies, examples of entire theses to download, study from, and cite.

Electronic Theses and Dissertations (ETDs)

http://www.library.wise.edu/libraries/Memorial/elecdiss.htm

This web site provides link to the ETD initiative at the University of Wisconsin-Madison. 
It includes links to: the Dissertation Abstracts On Disc database, Sites Currently Providing Some Full Text Access to Dissertations, Information About Electronic Dissertation Initiatives.

Electronic Theses and Dissertations: Problems and Possibilities http://www.cas.usf.edu/english/walker/papers/etds/bibliog.html

This is an annotated bibliography and includes links to what universities are doing, what the students are doing, what is being said about ETD, what formats are being used. Christian Weisser, John Baker, Janice R. Walker, University of South Florida, Department of English.

Electronic Theses and Dissertations in the Humanities http://www.cs.queensu.ca/achallc97/papers/p037.html

Matthew Kirschenbaum, University of Virginia and Edward Fox, Virginia Polytechnic Institute and State University (Virginia Tech) wrote this article on ETD Implementation at Virginia Tech. Hypertext and multimedia theses and dissertations, archival considerations and other issues were discussed. By Matthew G. Kirschenbaum and Edward A. Fox.

Humanist: An Electronic Seminar for Humanities Computing http://www.princeton.edu/ mccarty/humanist/announcement.html

This web site includes discussion of ETDs.

National Digital Library of Theses and Dissertations: A Scalable and Sustainable Approach to Unlock University Resources http://www.dlib.org/dlib/september96/theses/09fox.html

This is an article published in D-Lib Magazine. By Edward A. Fox and others.

Networked Digital Library of Theses and Dissertations http://www.ndltd.org/

This web site provides information about the Networked Digital Library of Theses and Dissertations Initiative whose objective is: "To improve graduate education by allowing students to produce electronic documents, use digital libraries, and understand issues in publishing; To increase the availability of student research for scholars and to preserve it electronically; To lower the cost of submitting and handling theses and dissertations; To empower students to convey a richer message through the use of multimedia and hypermedia technologies; To empower universities to unlock their information resources and To advance digital library technology." 
http://web.ufllb.ufl.edu/rs/catpro/umi-theses.html

This is a pilot project at the University of Florida to test workflow for cataloging photocopies of University Microfilm (UMI) theses and dissertations.

Steps of the ETD Submission Process

http://www.swem.wm.edu/ETD/process.html

This web site provides a guideline on ETD submission.

WSU Dissertations: Policies and Procedures for Receipt and Submission of Digital Dissertations and Theses

http://www.dissertations.wsu.edu/p\&pforddt.htm

This web site provides links to Washington State University's guidelines and policies for EDT.

Yale Dissertations: Cataloging of Microfilm Copy at Minimal-Level http://www.library.yale.edu/cataloging/artsciteam/dismic.html

This is a guideline for cataloging dissertations at Yale University Library.

\section{DICTONARIES, ENCYCLOPEDIAS, AND PLACE NAMES}

\section{Foreign Language Dictionaries}

This section includes selected foreign language dictionaries that are available on the Internet and that do not require passwords or fees to obtain access.

Czech-English On-line Dictionary http://dictionaries.travlang.com/CzechEnglish/ http://dictionaries.travlang.com/EnglishCzech/

These dictionary databases are from the freeware multilingual program Ergane. It searches for any entry in both directions and it contains 1,900 terms. It is easy to use.

Finnish-English On-Line Dictionary http://dictionaries.travlang.com/FinnishEnglish/ http://dictionaries.travlang.com/EnglishFinnish/

These dictionary databases are from the freeware multilingual program Ergane. It searches for any entry in both directions and it contains 1,800 terms. It is easy to use.

English-Finnish-English On-Line Dictionary

http://efe.scape.net/ 
This dictionary searches for any entry in both directions. It is easy to use.

ARTFL Project: University of Chicago

http://humanities.uchicago.edu/forms_unrest/FR-ENG. html

This site contains a French-English dictionary with over 75,000 terms, reference guide, a database of French literature with over 2,000 texts, and links to other French language resources. The dictionary searches for any entry in both directions. It is an excellent research tool for students and scholars in French studies.

German-English-German Dictionary http://dict.tu-chemnitz.de/dings.cgi? searchform-l\&noframes $=0$

This dictionary searches for any entry in both directions. It is a simple dictionary based on a wordlist of about 140,000 entries. This service is provided by the Technische Universitat at Chemnitz.

The New English-German Dictionary http://www.iee.et.tu-dresden.de/cgi-bin/cgilvrapAvernerr/search.sh/

This dictionary searches for any entry in both directions. It contains about 190,000 words. This is a reference database, not a translator. It is simple to use.

Greek-English

http://www.arts.cuhk.edu.hk/Lexis/Latin/

The search can also be done using the Roman alphabet and Ancient Greek by selecting the appropriate checkbox. It is simple to use.

Free Online Bi-Directional English-Japanese Dictionary http://dict.pspinc.com/

This dictionary searches for any entry in both directions. The dictionary is not designed to accept romanized Japanese input. It is easy to use.

Latin-English Dictionary

http://www.arts.cuhk.edu.hk/Lexis/Latin/

This dictionary searches for any entry in both directions. This dictionary covers about 8,000 headwords. It is easy to use.

Spanish-English

http://tairona.apana.org.au/es/

This dictionary searches for any entry in both directions. It contains more than 60,000 
words.

Swedish-English-Swedish Dictionary

http://www.foreignword.com/dictionary/Swedish/default.htm

This dictionary searches for any entry in both directions. It is easy to use.

\section{English Language Dictionaries}

This section includes selected dictionaries for the English language that are available on the Internet and do not required passwords or fees.

America-British, British-American Dictionary

http://www.peak.org/ jeremy/dictionary/dictionary/

This web site provides a useful reference for the Briton in America and the American in Britain. The dictionary has two halves: American to British, where the explanation and definitions of American words are in British, and British to American, where British words are explained in American terminology and spellings. This dictionary is intended for Americans translating British, and Britons translating American. It is easy to use.

BritSpeak Dictionary

http://englishclub.8m.com/ukusI.htm

This dictionary searches for any entry in both directions. Many of the words in this dictionary are colloquialisms.

Hypertext Webster Gateway: Merriam Webster

http://smac.ucsd.edu/cgi-bin/http_webster

This hypertext Webster interface provides access to various dictionary services on the Internet. Users of this service type the word for which they want the definition, click to select either an exact match or an approximate match, and then click on the "Look up definition" button. Words are then hypertext linked back into the dictionary.

OneLook Dictionaries

http.//www.onelook.com/

This search engine provides access to words' definition or translation. The OneLook search engine indexes more than 4 million words in more than 800 online dictionaries.

\section{Encyclopedias}


This section includes selected encyclopedias which are available on the Internet and do not require passwords or fees.

Encyclopedia Smithsonian

http://www.si.edu/resource/faq/

This web site provides an answer to frequently asked questions about the Smithsonian with links to resources on subjects from Art to Zoology.

Encyclopedia.com. Electric Library

http.//www.encyclopedia.com/

This free encyclopedia provides users with more than 57,000 frequently updated articles from the Columbia Encyclopedia, 6th edition. Each article is linked to newspaper and magazine articles as well as pictures and maps-all provided by eLibrary. "eLibrary is the comprehensive digital archive for information seekers of all ages. You can search across 13 million documents from full-text newspaper and magazine articles, television and radio transcripts, international newswires, classic books, maps, photographs, as well as major works of literature, art and reference books. You'll find both current and historical events within the diverse eLibrary archive"-The web site.

PC Webopedia

http://www.pcwebopedia.com/

"Webopedia is a free online dictionary for words, phrases and abbreviations that are related to computer and Internet technology." Webopedia provides definitions to a wide range of computer knowledge. "In addition to the definition of the term or phrase, Webopedia also provides links to sources of further information on the topic, where applicable. Webopedia is part of the Internet. com network of Web sites owned and managed by Jupitermedia Corporation."-The web site

TechEncyclopedia

http://www.techweb.com/encyclopedia/

This resource covers over 13,000 definitions of computer technical terms and concepts from CMP's Tech Web.

\section{Place Names}

This section includes selected place names, which are available on the Internet and do not require passwords or fees.

Australian Geographic Place Names (Gazetteer)

http://www.nla.gov.au/pathways/jnls/newsite/view/263.html 
This web site provides free access to the "Gazetteer of Australia which is a compilation of geographic names of Australia provided by members of the Committee for Geographic Names in Australia. The data are as supplied by AUSLIG in June 1996."-The web site.

Canadian Geographical Names

http://geonames.nrcan.gc.ca/index.html

This is a database of over 500,000 place names of the Canadian metropolitan areas, cites, towns, villages, and other areas. The resources are in English and French. This site was produced by Natural Resources Canada.

Geographic Names Information System

http://www-nmd.usgs.gov/www/gnis/

http://geonames.usgs.gov/

The Geographic Names Information System (GNIS) is developed by the USGS in cooperation with the U.S. Board on Geographic Names (BGN). The GNIS is the Nation's official repository of domestic geographic names information. This database contains information about 2 million physical and cultural geographic features in the United States.

Geographic Names Links

http://geonames.usgs.gov/otherlinks.htmi

This database links geographic names of individual U.S. States, Antarctica, foreign countries, world, planetary, other related federal information servers, and miscellaneous geographic names sites.

GEOnet Names Server (GNS)

http://l64.214.2.59/geonames/gns_index-fr.htm

GEOnet is a database of world place names developed from the country gazetteers that were published by the U.S. Defense Mapping Agency (now the National Imagery and Mapping Agency). It contains place names for over 3.3 million features throughout the world.

Getty Thesaurus of Geographic Names

http://www.getty.edu/research/tools/vocabulary/tgn/index.html

"The Thesaurus of Geographic Names (TGN) contains about 1 million place names representing approximately 900,000 places. The thesaurus is composed of names and other information contributed by several Getty projects, including the Bibliography of the History of Art (BHA), the Foundation for Documents of Architecture (FDA), the Getty Center Photo Study Collection (GCPS), and the Getty Information Institute's Vocabulary Program (VP). We plan to expand our list of contributors both inside and outside the Getty ."-The web site. 
National Place Names Project

http://www.humanities.mq.edu.au/anps/links.htm

This site provides links to place names on the Internet. The resources are divided into Australian resources and overseas resources.

New Zealand Geographic Place-Names Database

http://www.linz.govt.nz/databases/'geographic/index.html

This database provides access to over 40,000 place names that appear on current New Zealand topographic maps and some historical maps.

Ordnance Survey-Gazetteer of Place Names (U.K.)

http://getamap.ordnancesurvey.co.uk/getamap/rnap.htm

This is an index to the 1:50, 000 Landranger series maps.

Place Name Servers on the Internet

http://www.asu.edu/lib/hayden/govdocs/maps/geogname.htm

This is a comprehensive list of place name servers on the Internet compiled by Arizona

State University Library. The resources are organized into these categories: United States Place Names Sites, World Place Names, Country Place Names, Planetary Place Names, and Just for Fun.

U.S. Gazetteer. U.S. Census Bureau

http://www.census.gov/cgi-bin/gazetteer/

This gazetteer is used to identify places to view with the Tiger (Topologically Integrated Geographic Encoding and Referencing System) Map Server and obtain census data from the 1990 Census Lookup server. Users can search by places, counties or MCD.

AUTOCAT Archives

http://ublib.bujfalo.edu/libraries/units/cts/autocat/search.html

This is a cataloging and authority discussion group sponsored by the Libraries of the University of Buffalo, State University of New York. Users can access and search the archive.

ALCTS Network News

http://www.ala.org/alcts/alcts_news/

ALCTS Newsletter Online is published monthly and is the official organ of the Association for Library Collections \& Technical Services.

ALCTS Taskforce on Meta Access

http://www.lib.virginia.edu/alcts/about.html 
This is an ALCTS taskforce group to investigate meta access. Final report is included on this web site.

Cataloging A to Z

http://home.hiwaay.net/ bparris/CCC/catAtoZ/index.html

This web site provides links to topics related to cataloging. It includes: Glossary,

AACR2, MARC, LCSH/Authority, Classification, Formats, Trends,

Workshops/Conferences, Journals, and Bibliography. In addition, it provides links to essential cataloging sites.

Cataloging E-Mail Lists and Newsgroups

http://www.itcompany.com/inforetriever/emailcat.htm

This resource is from Internet Library for Librarians. It includes cataloging E-Mail lists and newsgroups such as AUTOCAT, INTERCAT, Password for Windows, PURLs, SERIALIST, and others. Information given includes the title of the E-List, description, and the e-mail address.

CataList, the Official Catalog of LISTSERV

http://www.Isoft.com/lists/listref.html

This resource is the official catalog of all public discussion lists and it is updated regularly. It contains information on about 54,035 public LISTSERV groups. From this page, you can browse, search for mailing lists of interest, and get information about LISTSERV host sites. This information is generated automatically from LISTSERV's LISTS database and is updated automatically.

CONSERLine

http://lcweb.loc.gov/acq/conser/consrlin.html

This is a Newsletter of the CONSER Program and is published semiannually by the Library of Congress, Serial Record Division. It is a continuation of CONSER, a newsletter issued only in paper format. CONSERline is available in an electronic form only and is free of charge.

Liszt, the Mailing List Directory

http://www.liszt.corn/

A directory of over 90,000 discussion lists. You can search by topic and subscribe from this web site.

LITA Newsletter

http://www.lita.org/newslett/index.html 
This is published quarterly in an electronic format by the Library and Information Technology Association, a division of American Library Association.

Metamarda-1 Listserv Archive (by Date)

http://orc.dev.oclc.org:5103/metamarda-l/

This web site provides a link to the OCLC Metadata discussion archives by dates.

OCLC Newsletter

http://www.oclc.org/news/

This web site includes information on products, membership, research, worldwide news and new tools for librarians.

SERIALST

http://www.uvm.edu/ bmaclenn/serialst.html

SERIALST (Serials in Libraries Discussion Forum) is an informal electronic forum for topics relating to serials processing in libraries. This site includes the scope and purpose of SERIALST, as well as Fileserver information and selected command options.

Technical Services Law Librarian

http://www.aallnet.org/sis/tssis/tsll/tsll.htm

Discusses topics related to technical services for law librarians.

TSIG-L (Technical Services Interest Group)

http://www.fis.utronto.ca/people/affiliated/tsig/

Technical Services Interest Group of the Canadian Library Association, TSIG was designed to provide a forum for the communication and sharing of technical services issues and activities among members of the group.

USMARC-L

listserv@loc.gov

This moderated e-conference is open to anyone interested in discussing the implementation, maintenance, and development of the MARC 21 formats.

VIDEONEWS

listserv@library.berkeley.edu

Discusses cataloging issues related to videos.

Web4Lib Electronic Discussion

http://sunsite.berkeley.edu/Web4Lib/ 
The Web4Lib electronic discussion is for the discussion of issues relating to the creation and management of library-based World-Wide Web servers and clients. Topics of discussion include web site design, cataloging and metadata issues regarding web information, creating and maintaining secure public web stations, and training staff or users to use the web. The archive is available at http://sunsite.berkeley.edu/Web4Lib/archive.html.

WebCat-L

listserv@wuvmd.wustl.edu

WebCat-L is a forum for discussion on how web-interface catalogs should be designed. It is a very useful forum for library system vendors, librarians and users. The archive is available at: http://library.wustl.edu/ listmgr/webcat-l/.

\section{SOFTWARE AND VENDORS}

Book Where?-Links to Library Catalogs

http://www.web-clarity.com/products/overview_bookwhere.html

This is a software package that allows the user to search hundreds of databases for bibliographic information via the Internet.

Cataloging Software

http://www.itcompany.com/inforetriever/soft_cat.htm

This is a list of cataloging software, which was taken from "Internet Library for Librarians." It includes the following: Automated School Library Software, Book Organizer, CLARR, Collection Managers, FastCat for Windows and Desert FastCat for Windows 95, Hypertexted LCSH Classification of Computer-related Materials, Label Printer Plus, Latshaw Software, MARC Breaker, MARCit, MARC Makr, MARC View, PC-Card Catalog, and other useful software. It gives a description of each software.

Library of Congress Cataloging Distribution Service (CDS)

http://lcweb.loc.gov/cds/

This web site provides information on LC bibliographic products and services.

LSSI Library Services

http://www.pwl.com/lssi/welcome.html

This web site provides information about LSSI library services such as outsourcing, acquisitions and processing, circulation and other services.

Marcadia-Cataloging for Today from RLS 
http://www.rlg.org/marcadia.html

Marcadia is a vendor who can assist libraries by providing a range of activities such as cataloging, reclassification, and other services.

Marcive, Inc.

http://www.marcive.com/webl.htm

This web site provides a range of services to libraries such as cataloging, government documents, MARC 21 record enrichments, and MarciveWeb DOCS.

OCLC Web

http://www.oclc.org/home/

This is the OCLC webpage. It includes information on OCLC services, Librarian's toolbox, and other important information.

Search the OCLC Participating Institutions List http://www.oclc.org/oclc/forms/pisearch.htm

This site includes all the OCLC participating institutions, their symbols and policies. It gives instruction on how to search for the participating institutions.

RLIN

http://www.rlg.org/rlin.html

The Research Libraries Information Network (RLIN) is an internationally available bibliographic information system used with RLG's Library Resources. RLIN is used for cataloging and authority work, archives and manuscripts processing, and interli-brary loan. This site provides more information on RLIN search, contact and support service.

TECHNICAL SERVICES PROFESSIONAL ORGANIZATIONS

American Library Association (ALA)

http://www.ala.org/

The American Library Association (ALA) is the major librarians' association in the United States. This site provides links to ALA's News and Announcements; Events and Conferences; Library Advocacy and Support; Library Education and Employment; ALA Interests and Activities; ALA Marketplace; Membership Information and Services; ALA's Library; and ALA Divisions, Units, Governance.

American Society for Information Sciences and Technology (ASIST) http://www.asis.org/

The American Society for Information Sciences and Technology (ASIST) has been the society for information professionals leading the search for new and better theories, 
techniques, and technologies to improve access to information. Recently, the name changed from ASIS to ASIST. This web site provides links to information about ASIST, Membership, Electronic ASIST, Conferences and Meetings, Awards, Continuing Education, Special Interest Groups, Chapters, and Publications.

Association for College \& Research Libraries (ACRL) http://www.ala.org/acrl/

The Association for College and Research Libraries (ACRL) is a division of American Library Association (ALA). It is a professional association of academic librarians and other interested individuals. This web site provides links to information about the ACRL, Awards, Career Opportunities, Chapters, Events, Forms, Governance, Information Literacy, Membership, Publications, and other useful information.

Association for Library Collections \& Technical Services (ALCTS) http.//www.ala.org/alcts/

The Association for Library Collections \& Technical Services (ALCTS) is a division of American Library Association (ALA). ALCTS is responsible for the following activities: acquisition, cataloging, classification, and preservation of library materials; the development and coordination of the country's library resources; and those areas of selection and evaluation involved in the acquisition of library materials and pertinent to the development of library resources. This web site links to information about ALCTS, Annual Conference Program, Calendar and Events, Committee Meetings, Discussion Group Meetings, Awards, Membership, and Publications.

Canadian Library Association Technical Services Interest Group (TSIG) http://www.fis.utoronto.ca/people/affiliated/tsig/

The Canadian Library Association Technical Services Interest Group (TSIG) provides a forum for the communication and sharing of technical services issues and activities among members of the group in Canadian libraries. It provides links to Reference, People, TSIG-L, CLA/3M Award, Minutes of Meetings and Reports, Great Canadian TS Web Pages, and MARC Harmonization.

Center for Research Libraries (CRL)

http://wwwcrl.uchicago.edu/

This web site provides detailed information about the Center for Research Libraries, which will be useful for colleges, universities, and libraries. These links include information about CRL, Current CRL Members, CRL's Collection Program, CRL $\mathrm{Q} \ll a l o g$, CRL Collection Databases, How to Use the CRL Collections, How to Purchase From CRL, and Special Projects Currently Underway.

Committee on Cataloging: Description \& Access (CC: DA)-ALCTS http:/www.ala.org/alcts/organization/i/ccs/ccda/ccda.html 
The Committee on Cataloging: Description and Access (CC: DA) is the "body within the American Library Association responsible for developing official ALA positions on additions to and revisions of the Anglo-American Cataloging Rules, Second Edition, 1998 Revision."-The committee web site. This site provides links to general information, including committee's charge, reports, announcements, working documents, meetings, task forces, and other information.

IFLA Section on Cataloging

http://www.ifla.org/VII/sl3/sc.htm

The International Federation of Library Associations and Institutions (IFLA), Section on Cataloging analyses the function of cataloging activities for all types of materials and media for both bibliographic and authority information. This web site provides links to section Strategic Plan, Announcement, Medium-Term Program, Projects, Publications, Conference and Seminar, Minutes of Meetings, Annual Reports, and Useful Addresses.

IFLA Section on Classification and Indexing

http://www.ifla.org/VII/s29/sci.htm

The International Federation of Library Associations and Institutions (IFLA), Section on Classification and Indexing focuses on methods of providing subject access in cataloging, bibliographies, and indexes to documents of all kinds, including electronic documents. This web site provides links to the Section Strategic Plan, Announcement, Medium-Term Program, Publications, Annual Reports, and Useful Addresses.

Library and Information Technology Association (LITA)

http://www.lita.org/index.html

"Library and Information Technology Association (LITA) is a division of the American Library Association (ALA). It provides its members and the library and information science community as a whole with a forum for discussion, an environment for learning, and a program for actions on the design, development, and implementation of automated and technological systems in the library and information science field."-The web site. This site provides links to LITA's information including membership, awards, committees and interest groups, publications, annual programs, awards, and other related information.

Music Library Association (MLA)

http://www.musiclibraryassoc.org/

This site provides links to the Music Library Association (MLA) and includes information on all the MLA activities and events. This includes links to information about MLA organization, its Administration, Committees, Membership, Roundtables and Interest Groups, Awards and Grants, Annual Calendar, Publications, and Services. 
National Information Standards Organization (NISO)

http://www.niso.org/

The National Information Standards Organization (NISO), a nonprofit association accredited by the American National Standards Institute (ANSI), identifies, develops, maintains, and publishes technical standards to manage information in our changing and ever-more digital environment. NISO standards apply both traditional and new technologies to the full range of information-related needs, including retrieval, repurposing, storage, metadata, and preservation. This web site provides links to the following pages: NISO, Standards, Creating Standards, Become a member, Standards World, and International.

Newfoundland Library Association Links

http://www.infonet.st-johns.nf.ca/providers/nlla/assocs.html

This web site includes links to the resources about Canadian National Library Associations, Canadian Regional Library Associations, Other National/International Library Associations, Allied Professional Organizations in Newfoundland and Labrador as well as general lists of library professional organizations.

North American Serials Interest Group (NASIG)

http://nasig.org/

The North American Serials Interest Group (NASIG) is an independent organization that promotes communication and sharing of ideas among all members of the serials information chain-anyone working with or concerned about serial publications. This web site provides links to information about NASIG, Conferences, Contacts, Forms, lobs, Organization, Publications, Awards, Membership, and Resources.

Online Audiovisual Catalogers, Inc.

http://ublib.buffalo.edu/libraries/units/cts/olac/

This site provides a link to Online Audiovisual Catalogers (OLAC). OLAC was founded in 1980 to allow catalogers to exchange information about cataloging of audiovisual materials. This web site provides links to information about OLAC, What's New, NACO A/V, OLAC List, Handbook and Bylaws, Newsletter, Awards, Membership Form, Membership Directory, Book Reviews, and Useful Web Sites.

Program for Cooperative Cataloging (PCC)

http://lcweb.loc.gov/catdir/pcc/pcc.html

The Program for Cooperative Cataloging (PCC) is an international cooperative effort that helps libraries to effectively collaborate in providing bibliographic records based on mutually accepted standards of libraries around the world. This web site links to the components of the PCC: BIBCO, NACO, SACO, and CONSER. It also provides links to information on the PCC Organization, Annual Report and Statistics, Governance and 
Documentation, and Archived Documents.

Special Libraries Association (SLA)

http://www.sla.org/

The Special Libraries Association (SLA) is the international association representing the interests of information professionals in many countries. This web site provides links to information about SLA; Events Conferences, and Exhibits; SLA Career Services Online; Chapters, Divisions, and other units; Leadership; Member Services and Resources; Vendors and Partners; and other useful links.

\section{JOURNALS AND NEWSLETTERS}

ALCTS Publications and Resources

http://www.ala.org/alcts/publications/index.html

There are two official online journals of ALCTS:

ALCTS Newsletter Online

http://www.ala.org/alcts/alcts_news/

ALCTS Newsletter Online is published six times a year on the ALCTS web site. It covers current association news, events, updates, practices and developments in the field.

Library Resources \& Technical Services

http://www.ala.org/alcts/lrts/

Library Resources \& Technical Services (LRTS) is the official journal of the Association of Library Collections \& Technical Services, a division of the American Library Association. This journal is published quarterly and it covers library issues related to resource management and technical services.

American Libraries Online

http://www.ala.org/alonline/index.html

http://bubl.ac.uk/journals/lis/ae/amelib/

The American Library Association publishes this journal monthly, except bimonthly June/July. Subscription price is included in ALA dues. This journal covers general information on libraries. This includes feature articles on professional concerns and developments, along with news of the Association, library-related legislation, and libraries around the country and the world-The web site.

Cataloging \& Classification Quarterly

http://www.catalogingandclassificationquarterly.com/

Cataloging \& Classification Quarterly (CCQ) is published quarterly by The Haworth 
Press, Inc. It is an international journal and it covers all aspects of bibliographic organization. This includes articles on the principles, functions, and techniques of descriptive cataloging; the wide range of methods of subject analysis and classification; provision of access for all formats of materials including electronic resources; and the policies and planning leading to the effective use of bibliographic records in modern society-The web site.

College \& Research Libraries (C\&RL)

http://www.ala.org/acrl/c\&rl.html

College \& Research Libraries is published bimonthly by the Association of College \& Research Libraries, a division of the American Library Association. It is a research journal and it covers all aspects of the library science field related to academic research libraries.

College \& Research Libraries News

http://www.ala.org/acrl/c\&rlnew2.html

College \& Research Libraries News is published monthly by the Association of College $\&$ Research Libraries, a division of the American Library Association. It covers news from ALA and ACRL and publishes articles, reports, and essays written by practitioners addressing philosophy and techniques of day-to-day management of academic library services and collections-The web site.

CONSERLine

http://www.loc.gov/acq/conser/consrlin.html

Newsletter of the CONSER Program. It is issued by the Library of Congress, Serial Record Division. This electronic newsletter is a continuation of CONSER, a newsletter previously issued only in paper. It contains news of the CONSER Program and information of interest to the serials cataloging community.

Information Technology and Libraries

http://www.lita.org/ital/itall904.html

Information Technology and Libraries is published quarterly by the Library and Information Technology Association, a division of the American Library Association. The journal includes articles on all aspects of information technology specific to the library field. This includes digital libraries, metadata, authorization and authentication, electronic journals and electronic publishing, telecommunications, distributed systems and networks, computer security and intellectual property rights, technical standards, and other related information technology.

International Cataloging and Bibliographic. Control http://www.ifla.0rg/VI/3/admin/icbc.htm 
International Cataloging and Bibliographic Control (ICBC) is the quarterly journal of IFLA's Universal Bibliographic Control and International MARC 21 Program. It provides an international forum for the exchange of views and research results by members of the library and information management profession. It contains articles on bibliographic databases, cataloging issues, electronic publishing, and other related issues-The web site.

Journal of Internet Cataloging

http://www.haworthpressinc.com/jic/

http://internetcataloging.com/

The Journal of Internet Cataloging is an international journal and it is published quarterly by The Haworth Press, Inc. It focuses on the organization, access, and bibliographic control of Internet resources both theoretically and practically.

LC Cataloging Newsline

http://lcweb.loc.gov/cadir/lccrt/lccn.html

http://gort.ucsd.edu/newjour/l/msg02298.html

LC Cataloging Newsline is published irregularly by the Cataloging Directorate, Library Services, Library of Congress. It contains news of cataloging activities throughout the Library of Congress as well as related events and conferences.

Library and Information Science Research Journal (LIBRES)

http://libres.curtin.edu.au/

Library and Information Science Research Journal is an international bi-annual electronic journal and is published by the School of Media and Information, Curtin University of Technology, Perth, Western Australia. It is devoted to new research in library and information science.

OCLC Technical Bulletins

http.//www.oclc.org/technicalbulletins/

http://www.oclc.org/technicalbulletins/online.shtm

http://www.amigos.org/aaoc/200l/marOI/bulletins.html

This is published online by OCLC and covers all aspects of technical services related to

OCLC products and services. This includes new OCLC products, features, and options.

OCLC Newsletter

http://www.oclc.org/news/

This is issued by OCLC and covers news, research and product information related to library and information science.

OCLC Newsletter Archive

http://www.oclc.org/news/newsletter/ 
This is the archive of the OCLC Newsletter. It archives, by year, the OCLC news, research, product information related to library and information science.

The Serials Librarian

http://www.coleonline.us/serialslibrarian/

http://www.haworthpress.com/store/product.asp?sku=J 123

This is an international journal and it is published quarterly by The Haworth Press, Inc. It covers all aspects of management of serials in any format, e.g., print and electronic. This journal is essential for academic, large public and special libraries as well as to graduate students and scholars who want to know any aspect of the acquisition, evaluation, and organization of serials.

Technical Services Quarterly

http://www.haworthpress.com/store/product.asp?sku=J 124

Technical Services Quarterly is published by The Haworth Press, Inc. and covers new trends in computers, automation and advanced technologies in the technical operation of libraries of all types and information centers.

\section{NOTES}

Many web sites were consulted during my work on this project. Among them were:

1. Library of Congress http://www.loc.gov/.

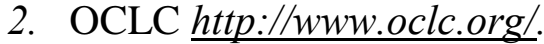

3. Internet Library for Librarians http://itcompany.com/inforetriever/aojt cat.htm.

4. Library Cataloging Aids http://www3.ns.sympatico.ca/allegrow/cat.htm.

5. Using the Internet in Technical Services http://arapaho.nsuok.edu/ west/okca.

6. Cataloger's Toolbox http://www.mun.ca/library/cat/formatool.htm.. 